\title{
Management strategies for banana Xanthomonas wilt in Rwanda include mixing indigenous and improved cultivars
}

\author{
Florence Uwamahoro $^{1,2}$ (D) $\cdot$ Anna Berlin ${ }^{1} \cdot$ Helena Bylund ${ }^{3} \cdot$ Charles Bucagu $^{4} \cdot$ Jonathan Yuen $^{1}$
}

Accepted: 5 March 2019 / Published online: 21 March 2019

(C) The Author(s) 2019

\begin{abstract}
Xanthomonas wilt is a major constraint to banana production in the East and Central Africa. The disease can cause up to 100\% yield losses if proper management strategies are not well implemented. Understanding of disease status, driving factors and farmers' knowledge provide insights towards a sustainable management approach. A total of 120 and 150 banana farms from eight and ten districts of Rwanda were surveyed for disease occurrence in 2015 and 2016 respectively. The owners of the farms were interviewed about disease knowledge, management practices, and source of information in these aspects. The results show that Xanthomonas wilt was present in all surveyed districts with high incidence (above 45\% in both 2015 and 2016) in major banana growing areas, highlighting the risk of increasing yield losses. High Xanthomonas wilt incidence and severity was associated with Impara and Eastern plateau agro-ecological zones, intercropping systems, brewing bananas, dense spacing, and homogenous cultivars. Here, we demonstrate for the first time the gravity of Xanthomonas wilt in major banana growing areas of Rwanda. This agrees with the finding that proper implementation of management practices by the farmers remains limited. Disease management difficulties could be attributed to inaccessibility to the right information since some information sources may be unreliable. We also report for the first time that fields with a mixture of indigenous and improved cultivars are likely to have low Xanthomonas wilt disease severity $(p<0.005)$, and this could be considered in banana Xanthomonas wilt management package. Our findings are essential to understand the urgency of improving extension services with updated practices and reinforcing disease monitoring efforts in order to stop new infections and further spread of the Xanthomonas wilt disease, a threat to sustainable banana production in Rwanda.
\end{abstract}

Keywords Musa spp. A Agro-ecological zones · Xanthomonas campestris pv. musacearum · Cultivars' mixture · Disease awareness $\cdot$ Disease management practices

\section{Introduction}

Florence Uwamahoro

florence.uwamahoro@slu.se; umflora@gmail.com

1 Department of Forest Mycology and Plant Pathology, Swedish University of Agricultural Sciences, Box 7026, SE-750 07 Uppsala, Sweden

2 Department of Crop Science, College of Agriculture, Animal Sciences and Veterinary Medicine, University of Rwanda, Box 210, Musanze, Rwanda

3 Department of Ecology, Swedish University of Agricultural Sciences, Box 7044, SE-750 07 Uppsala, Sweden

4 Rwanda Agriculture Board, Ministry of Agriculture and Animal Resources, Box 5016, Kigali, Rwanda

Banana (Musa spp.) is an important staple crop grown for both subsistence and income generation by smallholder farmers in the Great Lakes region of East and Central Africa. Rwanda is part of the region, and banana is one of the most important staple food crops (Karamura et al. 2012) occupying 23\% of the area cultivated and contributing to $28 \%$ of the total crop production (NISR 2016). Globally, the crop is mostly known for producing sweet dessert fruits, but in East Africa many cultivars are grown for their starchy fruits that are roasted or cooked and cultivars with bitter and astringent fruits that are used for brewing beer (Karamura et al. 2012). In addition, bananas' robust and perennial features play an important role in protecting soil from erosion on hilly terrain, and banana plant parts are used as livestock fodder, for making baskets, carpets, shoes and indoor decorations (Karamura et al. 2008).

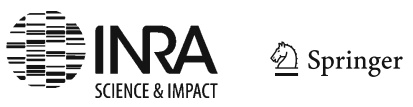


Currently, the banana Xanthomonas wilt disease caused by Xanthomonas campestris pv. musacearum is the major constraint to banana production in the East and Central Africa (Nkuba et al. 2015). The disease was originally reported on the banana relative enset (Ensete ventricosum) in 1968 and a few years later on banana in Ethiopia (Yirgou and Bradbury 1974). In the Great Lakes region of East and Central Africa, it was first reported in central Uganda in 2001; and from there, it spread to the Democratic Republic of Congo, Rwanda, Tanzania, Kenya, and Burundi (Carter et al. 2010). In Rwanda, since the first report of the disease during 2005 in Rubavu district, the disease has progressively spread to other areas (Reeder et al. 2007). In 2007, banana Xanthomonas wilt was present in three districts namely Rubavu, Rutsiro, and Rulindo (Murekezi 2009), and a few years later in 20092010 , the disease was present in 9 out of 12 surveyed districts (Night et al. 2013).

The bacterium, Xanthomonas campestris pv. musacearum, is highly transmissible and spreads rapidly through infected plant material, cutting tools, long-distance trade, and vectors such as insects, birds, and bats (Tinzaara et al. 2011) (Fig. 1). Moreover, lack of knowledge among farmers on disease diagnosis and management, and cultural practices such as the use of unsterilized cutting tools that unintentionally spread the bacteria, contributed to its rapid spread (Mwangi and Nakato 2009). The bacterium attacks all cultivars, and no single method is effective to control the disease. Effective management requires a set of cultural practices (planting healthy suckers, breaking of male buds with a forked stick, disinfection of farm tools, and removal of infected plants) that need to be applied as a package (Kubiriba and Tushemereirwe 2014). But, some farmers do not adhere to this recommendation due to the associated high labor cost and perceptions on effectiveness of the disease management practices, resulting in continued disease spread (Jogo et al. 2013; Rutikanga et al. 2013).

Since the first report of Xanthomonas wilt in Rwanda, several campaigns and efforts have been initiated by the Ministry of Agriculture through Rwanda Agriculture Board in collaboration with local government and other stakeholders to raise awareness among farmers to combat the disease (Murekezi 2009). Despite these efforts, the disease continued to spread (Night et al. 2013). A previous study showed the distribution, incidence, and farmer knowledge of banana Xanthomonas wilt in Rwanda during 2009-2010 (Night et al. 2013).

\section{Infection pathways for banana Xanthomonas wilt disease} damaged plant parts to the soil

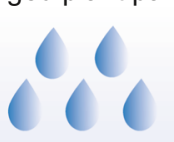

Moving infected suckers to a new farm
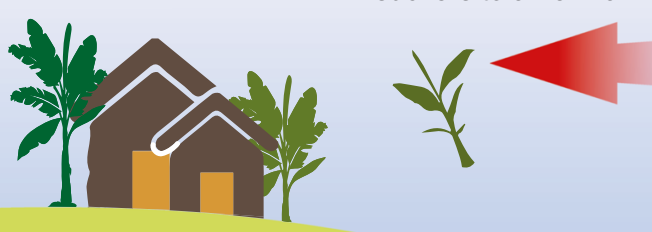

Transmission by animals through plant injuries and infested soil to
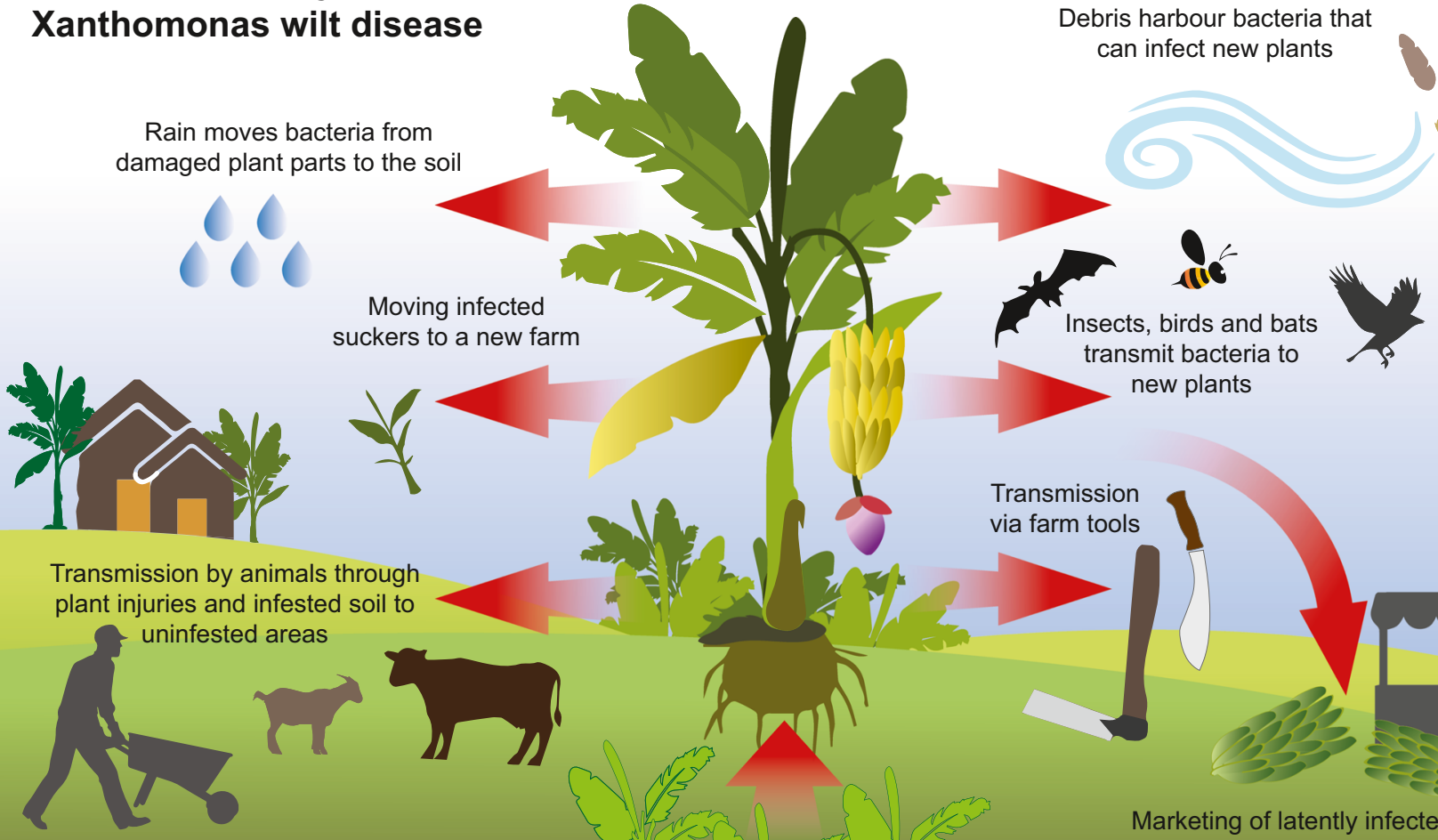

Debris harbour bacteria that can infect new plants

Infected garden plants
are source of inoculum

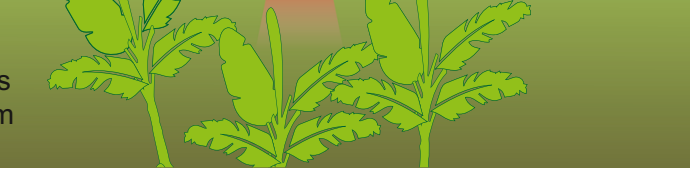

Marketing of latently infected bananas contribute to long distance dispersal

Fig. 1 Transmission means of the bacterium Xanthomonas campestris pv. musacearum causing banana Xanthomonas wilt. The bacterium is spread by everything that gets in contact with an infected banana, such as insects and birds sucking nectars or feeding on ripen fruits, grazing animals, cutting tools, and unintentional moving of infected soils on boots, symptomless infected suckers, or marketed infected banana 
However, considering severe impact of the disease, keeping track of its status and farmers' knowledge over time would help to understand the factors responsible of its continual spread or persistence. This study was therefore conducted to assess the distribution of Xanthomonas wilt in Rwanda during two consecutive years (2015 and 2016) and to determine the factors associated with disease occurrence. An interview study was performed to evaluate the farmers' knowledge on the detection, spread, and management of banana Xanthomonas wilt and to study the actual application of disease management strategies as well as the source of knowledge.

\section{Materials and methods}

\subsection{Survey sites selections}

Banana Xanthomonas wilt surveys were conducted during March-April 2015 in four agro-ecological zones (Birunga, Buberuka, Central Plateau, and Eastern Plateau) and during March-April 2016 in five agro-ecological zones (same zones as in 2015 plus Impara) (Fig. 2). Impara agro-ecological zone was only surveyed in 2016. The zones were selected in order to reflect the distribution of banana Xanthomonas wilt around the country. Impara, Eastern Plateau, and Kivu lake border are the major banana growing agro-ecological zones of Rwanda, with topography and climatic conditions suitable for banana (Nsabimana et al. 2008). In each zone, two districts were selected randomly. Three locations per district (a location being a sector in major banana growing districts or a cell in minor banana growing districts) were selected in consultation with districts agricultural officers, in order to cover locations where banana plantations dominate. A stratified random sampling was used to select five farms from each location departing from the center of each location and following the direction with more banana mats. A stratum was taken to be a farm with at least 30 banana mats under production, and at least $1 \mathrm{~km}$ distance from one farm to the next was considered. In total, 120 farms in 2015 and 150 farms in 2016 were surveyed for banana Xanthomonas wilt, and the farm owners were interviewed. In districts surveyed during both 2015 and 2016, the same farms were visited twice, and the interviews were performed during the first visit.

\subsection{In-field Xanthomonas wilt disease assessment}

At each of the selected farms, the survey team, consisting of two enumerators and a researcher, visited the banana field

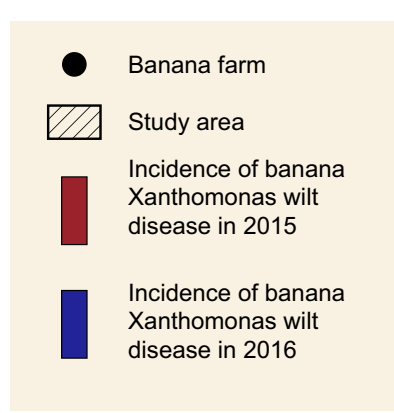

Agro-ecological zones

\begin{tabular}{|l}
\hline Congo nile watershed divide \\
Impara \\
Imbo \\
Eastern savanna \\
\hline Mayaga \\
Bugesera \\
Buberuka highlands \\
Birunga \\
Kivu lake border \\
Eastern plateau \\
Central plateau
\end{tabular}

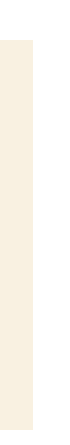

(n)

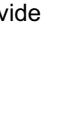

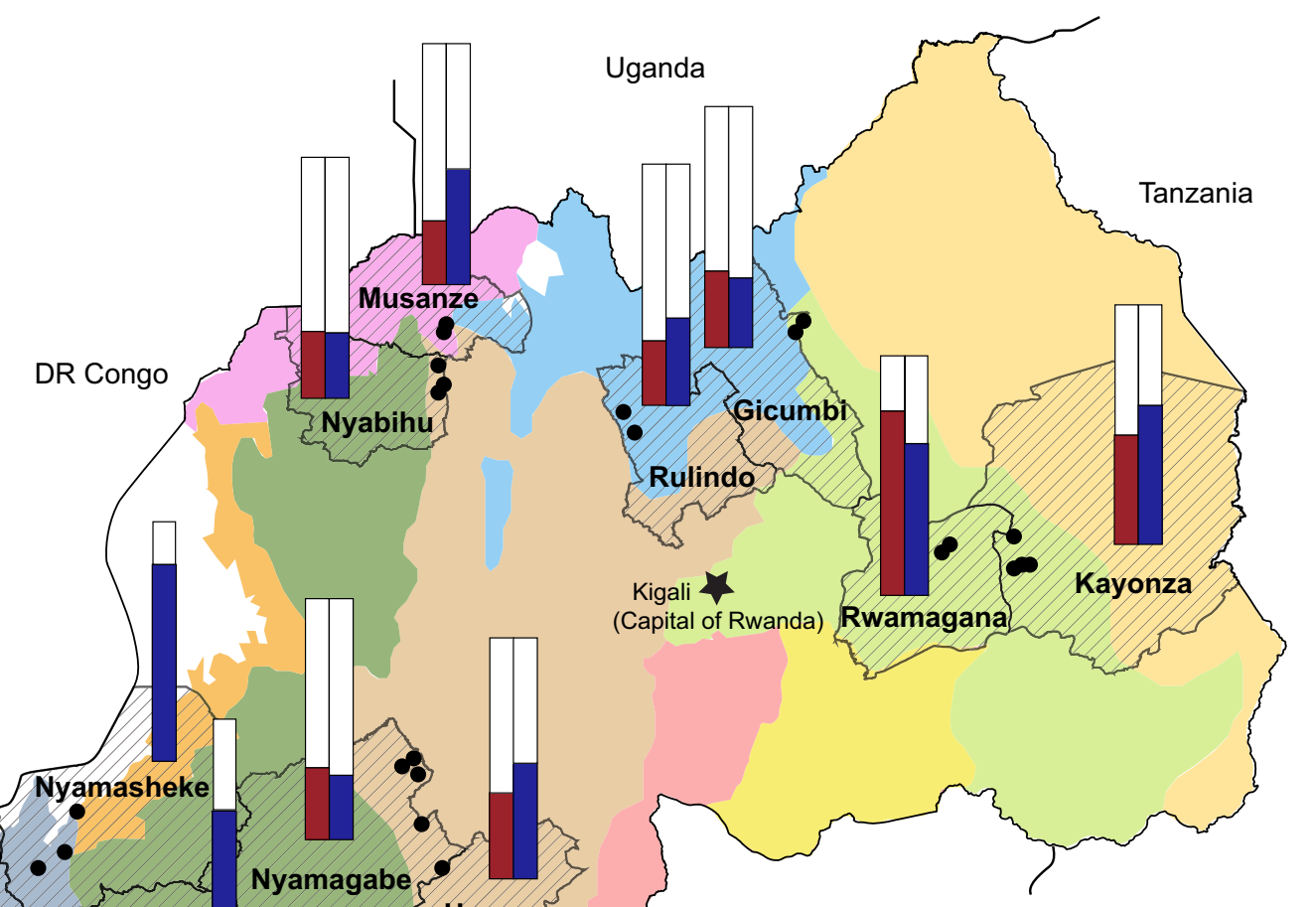

Burundi

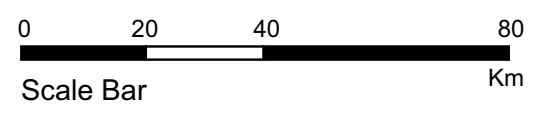

Fig. 2 Agro-ecological zones of Rwanda based on differences in climatic, topographic, and edaphic environment (Verdoodt and Van Ranst 2006) and banana Xanthomonas wilt distribution in the surveyed districts during 2015 and 2016. The disease was present in all surveyed districts. Black dots indicate some surveyed farms, and bars show Xanthomonas wilt incidence in 2015 and 2016 
closest to the farmer's home to assess Xanthomonas wilt and identify the farming practices applied by the farmer. A global positioning system device was used to record geographical coordinates of the farms.

Visual symptoms such as yellowing and wilting of leaves, premature and uneven fruits ripening, yellowish blotches and dark brown scars in the pulp, and yellow ooze from cut pseudostems were used to confirm that the disease was Xanthomonas wilt (Tripathi et al. 2009) (Fig. 3). From the center of each field, we made two diagonal lines, and five banana mats from each line were selected to assess the incidence and severity of Xanthomonas wilt. The incidence was calculated for each field as the percentage of symptomatic mats of the total number of surveyed mats. The severity was recorded for each surveyed mat based on a 1-5 severity scale transformed into percent wilting, where scale $1=0 \%$ wilting, $2=20 \%$ wilting, $3=50 \%$ wilting, $4=75 \%$ wilting, and $5=$ $100 \%$ wilting. The average wilting percentage for surveyed mats per field gave the disease severity for that field.

\subsection{Interviews}

The interviews were face to face with the farmers and were performed in the local language (Kinyarwanda). The questionnaire included both open and closed questions. Closed questions included questions about farming practices, applied disease management practices, and the source of acquired knowledge on Xanthomonas wilt. Open questions included farmers' knowledge on disease detection, spread, and management. To assess the source of knowledge about the disease,
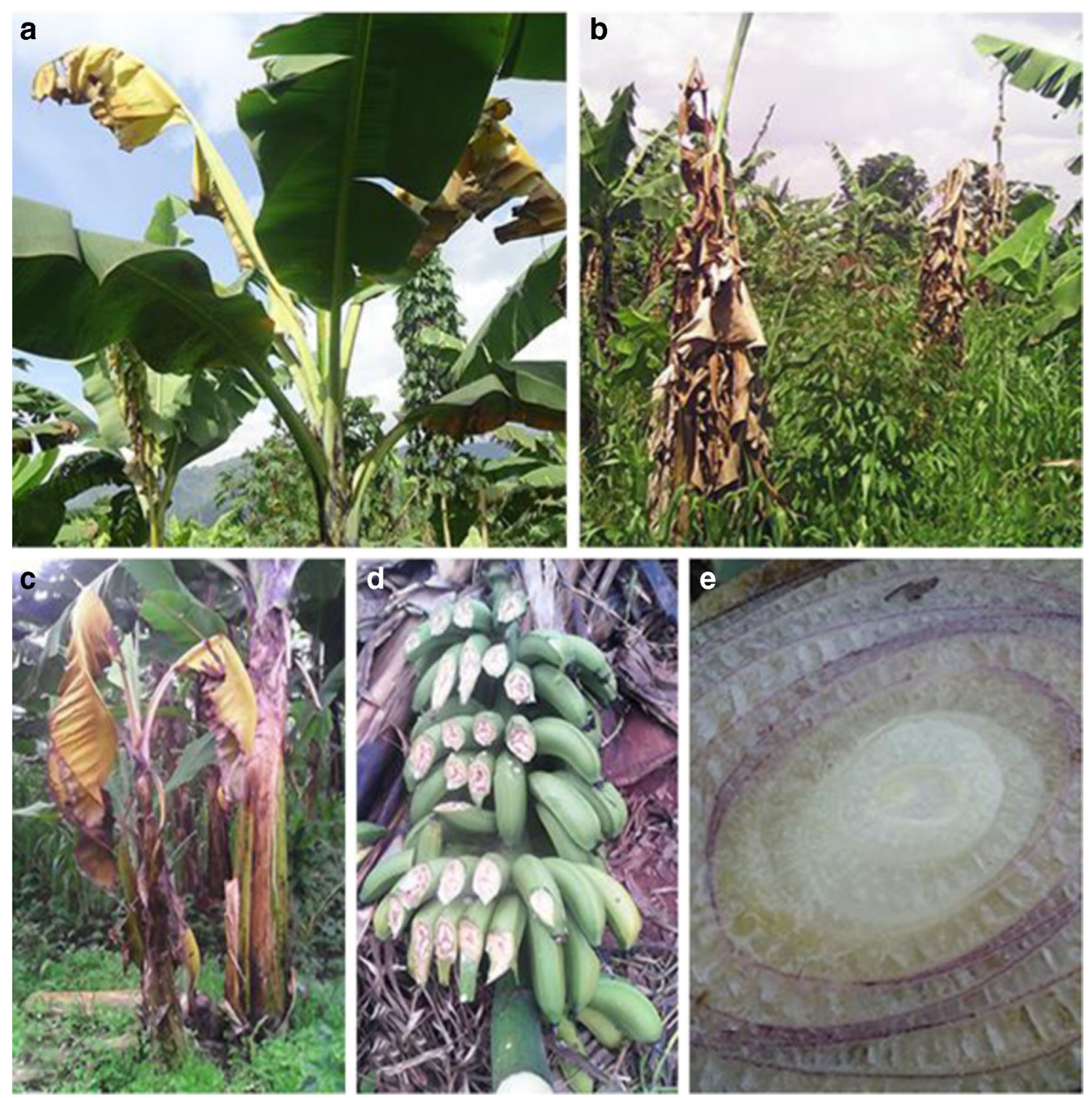

Fig. 3 Symptoms of banana Xanthomonas wilt are a yellowing of the leaves, $\mathbf{b}$ wilting of the whole plant, $\mathbf{c}$ symptomatic banana sucker, $\mathbf{d}$ cross-sections of the banana fingers showing rusty brown stains, e yellow bacterial ooze from a cut pseudostem 
the farmers were asked to mention sources that provided them the information on Xanthomonas wilt disease in a list of 15 possible sources (agronomists, brochures, extension officers, fellow farmers, local leaders, Ministry of Agriculture (MINAGRI), newspapers, non-government organizations (NGOs), parents or other relatives, posters, Rwanda Agriculture Board (RAB) scientists, researchers, radio, television, and training).

\subsection{Statistical analyses}

The relationship between Xanthomonas wilt incidence or severity with independent variables was tested in single, multiple, and reduced models (Uwamahoro et al. 2018) by using logistic regression in $R$ statistical software (Everitt and Hothorn 2006). Thirteen independent variables were used and categorized into variable classes. These variables and their respective classes include agro-ecological zones (Buberuka, Birunga, Central plateau, Eastern plateau, Impara), banana types (cooking, brewing, dessert), cropping systems (monocropping, intercropping), first farm appearance (before 2010, 2010 to 2013, after 2013), grown cultivars (indigenous, improved, a mixture of both indigenous and improved), spacing between mats (wide, moderate, dense), sampling year (2015 or 2016), source of planting materials (own farms, other farmers, certified multipliers or governmental institutions), sterilizing farm tools (yes, no), exchanging farm tools (yes, no), exchanging planting materials (yes, no), removing male bud (yes, no), and using own tools in someone else's farm (yes, no).

Logistic regression calculates the probability of a given binary outcome (response) as a function of the independent variables (Everitt and Hothorn 2006). Hence, Xanthomonas wilt incidence and severity percentage were classified into distinct categories of binomial qualitative data. Class boundaries of $<30 \%$ and $\geq 30 \%$ for incidence and severity were chosen so that groups contained approximately equal totals, thus, yielding a binary dependent variable. The single model tested the association of each independent variable alone with the disease incidence or severity. In multiple models, the association of each independent variable with disease incidence or severity was tested when entered last into the model with all other independent variables. Only the variables that showed high association to disease incidence or severity in a single and multiple models were tested in the reduced multiple models as described in Uwamahoro et al. (2018). The final analysis of deviance table generated in the reduced multiple models is shown in Table 1. The parameter estimates and standard error of the parameter estimates are given by generalized linear model (glm) in logistic regression, whereas the odds ratio interpreted as the relative risk here is obtained by exponentiation of the parameter estimates (Everitt and Hothorn 2006).

\section{Results and discussion}

\subsection{Distribution of banana Xanthomonas wilt}

Banana Xanthomonas wilt remains the major threat to banana production in East and Central Africa. This study conducted in Rwanda in 2015 and 2016 shows that the disease was present in all surveyed districts. During 2015, the incidence of Xanthomonas wilt varied from 27 to $77 \%$ and was higher (> $45 \%$ ) in the two major banana growing districts Rwamagana and Kayonza (Fig. 2). In the 2016 survey, the minimum and maximum incidences were reported in the districts of Nyamagabe (26\%) and Nyamasheke (82\%) respectively. Notably, higher incidences (above 58\%) were recorded in the following major banana growing districts: Rwamagana, Kayonza, Rusizi, and Nyamasheke in 2016 (Fig. 2).

The presence of banana Xanthomonas wilt in all surveyed districts indicates that despite the efforts and campaigns to combat the disease (Murekezi 2009) it continued to spread across the country if compared with the report from 2009 to 2010 (Night et al. 2013). A similar pattern was observed in the Kagera region of Tanzania (Shimwela et al. 2016). The continued spread of banana Xanthomonas wilt in East and Central Africa can be attributed to inappropriate application of management practices, lack of appropriate methods for farm tools disinfection, and failure in applying regulations and quarantine measures (Tinzaara et al. 2011). It was also noted that many farmers abandoned control measures because they were stunned by the devastation of the disease (Tushemereirwe et al. 2008). Similarly, some farmers expect immediate results from disease control practices; if that is not the case, they drop the implementation of control measures (Tinzaara et al. 2011).

\subsection{Relationship between banana farming practices and agro-ecological location with Xanthomonas wilt incidence and severity}

Among the 13 variables tested in single and multiple models in association with Xanthomonas wilt incidence and severity, only agro-ecological zone, spacing, banana type, and cropping systems were significantly $(p<0.05)$ associated with incidence. Similarly, the agro-ecological zone, cropping system, banana type, and cultivars were significantly $(p<0.05)$ associated with severity in single and multiple models. These variables associated with incidence and severity in both models were checked in the reduced model where the odds ratio helped to assess the contribution of each variable class (Table 1). The first farm appearance variable was not associated with the disease incidence, but for the fit of the model, it was kept since the AIC (Akaike Information Criterion) (Akaike 1974) substantially increased when it was removed. High incidence of Xanthomonas wilt ( $\geq 30 \%$ ) was positively associated with major banana growing zones, intercropping 
Table 1 Analysis of deviance, natural logarithms of odds ratio, and standard error of added variables in the reduced model analyzing banana Xanthomonas wilt incidence and severity in Rwanda ${ }^{a}$

\begin{tabular}{|c|c|c|c|c|c|c|c|c|}
\hline \multirow[t]{2}{*}{ Independent variables ${ }^{\mathrm{b}}$} & \multirow[t]{2}{*}{ Residual deviance } & \multirow[t]{2}{*}{ DF } & \multicolumn{2}{|l|}{ LRT } & \multirow[t]{2}{*}{ Variable class } & \multirow{2}{*}{$\begin{array}{l}\text { Estimates }{ }^{\mathrm{c}} \log \mathrm{e} \\
\text { (odds ratio) }\end{array}$} & \multirow[t]{2}{*}{$\mathrm{SE}$} & \multirow[t]{2}{*}{ Odds ratio } \\
\hline & & & DR & $\operatorname{Pr}>\chi^{2}$ & & & & \\
\hline \multicolumn{9}{|c|}{ Xanthomonas wilt incidence } \\
\hline Intercept & 251.38 & & & & & 1.68 & 2.41 & 5.38 \\
\hline \multirow[t]{5}{*}{ AEZ } & 237 & 4 & 14.38 & $<0.0001$ & Buberuka & $0^{\mathrm{d}}$ & - & 1 \\
\hline & & & & & C. Plateau & 0.07 & 0.70 & 1.08 \\
\hline & & & & & E. Plateau & 0.41 & 0.62 & 1.51 \\
\hline & & & & & Impara & 1.61 & 0.84 & 5.02 \\
\hline & & & & & Birunga & -0.19 & 0.60 & 0.82 \\
\hline \multirow[t]{2}{*}{ Cropping system } & 217.42 & 1 & 19.58 & $<0.0001$ & Intercropping & $0^{d}$ & - & 1 \\
\hline & & & & & Monocropping & -0.63 & 0.43 & 0.53 \\
\hline \multirow[t]{3}{*}{ Banana type } & 188.24 & 2 & 29.18 & $<0.0001$ & Brewing & $0^{\mathrm{d}}$ & - & 1 \\
\hline & & & & & Cooking & -2.20 & 0.49 & 0.11 \\
\hline & & & & & Dessert & -1.38 & 0.62 & 0.25 \\
\hline \multirow[t]{3}{*}{ Spacing } & 179.73 & 2 & 8.50 & $<0.0001$ & Wide & $0^{\mathrm{d}}$ & - & 1 \\
\hline & & & & & Dense & 1.69 & 0.56 & 5.43 \\
\hline & & & & & Moderate & 0.81 & 0.47 & 2 \\
\hline \multirow[t]{3}{*}{ First farm appearance } & 175.29 & 2 & 4.44 & 0.11 & After 2013 & $0^{d}$ & - & 1 \\
\hline & & & & & 2010-2013 & -0.05 & 0.52 & 0.95 \\
\hline & & & & & Before 2010 & -1.25 & 0.68 & 0.29 \\
\hline \multicolumn{9}{|l|}{ Xanthomonas wilt severity } \\
\hline Intercept & 372.16 & & & & & 1.29 & 0.50 & 3.64 \\
\hline \multirow[t]{5}{*}{ AEZ } & 347.33 & 4 & 24.84 & $<0.0001$ & Buberuka & $0^{d}$ & - & 1 \\
\hline & & & & & C. plateau & -0.84 & 0.47 & 0.43 \\
\hline & & & & & E. plateau & 0.78 & 0.47 & 2.17 \\
\hline & & & & & Impara & 2.01 & 0.65 & 7.50 \\
\hline & & & & & Birunga & 0.17 & 0.46 & 1.18 \\
\hline \multirow[t]{2}{*}{ Cropping system } & 307.95 & 1 & 39.38 & $<0.0001$ & Intercropping & $0^{\mathrm{d}}$ & - & 1 \\
\hline & & & & & Monocropping & -0.80 & 0.34 & 0.45 \\
\hline \multirow[t]{3}{*}{ Banana type } & 267.98 & 2 & 39.97 & $<0.0001$ & Brewing & $0^{\mathrm{d}}$ & - & 1 \\
\hline & & & & & Cooking & -2.03 & 0.39 & 0.13 \\
\hline & & & & & Dessert & -2.31 & 0.50 & 0.10 \\
\hline \multirow[t]{3}{*}{ Grown cultivars } & 257.44 & 2 & 10.53 & 0.005 & Improved & $0^{\mathrm{d}}$ & - & 1.00 \\
\hline & & & & & Indigenous & 0.84 & 0.35 & 2.32 \\
\hline & & & & & Mixed & -1.14 & 0.78 & 0.32 \\
\hline
\end{tabular}

${ }^{a} D F$ degree of freedom, $L R T$ likelihood ratio test, $D R$ deviance reduction, $\operatorname{Pr}$ probability of a $\chi 2$ value exceeding the deviance reduction, $S E$ standard errors, $A E Z$ agro-ecological zones. Dense spacing ( $<1 \mathrm{~m}$ between mats), moderate spacing (between 1 and $2 \mathrm{~m}$ ), wide spacing ( $\geq 2 \mathrm{~m}$ between mats). ${ }^{\mathrm{b}}$ Terms are added sequentially from first to last in order of presentation in the table. ${ }^{\mathrm{c}}$ Estimates are from the model with all independent variables added;

${ }^{\mathrm{d}}$ The reference category

system, brewing banana type, and dense and moderate spacing. Similarly, higher disease severity $(\geq 30 \%)$ was associated with major banana growing zones, intercropping systems, brewing type, and homogenous cultivation of either improved or indigenous cultivars (Table 1).

The highest disease incidence was observed in major banana growing areas, Impara and Eastern plateau (Fig. 2, Table 1). This could be attributed to the fact that nearly every farmer in these areas has a banana field, which helps the bacteria to spread rapidly across farms (Fig. 1). In addition, banana grows well at altitudes below $1700 \mathrm{~m}$ above sea level, as the altitude decreases the temperature increases and insect activity increases (Jaworski and Hilszczański 2013), leading to high disease spread by insects (Mwangi et al. 2006). High incidence in the Impara could also be explained by the fact that this region borders two countries, Democratic Republic of Congo and Burundi, where the disease prevalence is also high
(Carter et al. 2010) and that informal banana trade between countries is not strictly regulated.

Xanthomonas wilt incidence was two times lower in pure stand than in intercropped banana (Table 1). These findings are in agreement with another study that intercropped bananas are more prone to Xanthomonas wilt disease (Ocimati et al. 2013). This is probably because the farmers visit intercropped fields more frequently for managing annual crops using tools that can cause injury to banana roots, hence creating entry points for disease-causing pathogens (Rutikanga et al. 2013; Tushemereirwe et al. 2008). We observed five times higher incidence in densely planted banana fields compared with wide-spaced fields (Table 1). In densely spaced bananas, the short distance between the banana root systems and flowers can facilitate easy transmission of the disease-causing bacteria (Fig. 1). The predominance of Xanthomonas wilt incidence and severity in the brewing banana type have also been 
previously demonstrated (Tripathi et al. 2009); this is mainly due to high sugar content in the flower nectar, which attracts a diversity of insects (Tinzaara et al. 2011).

This study showed a significant association of Xanthomonas wilt severity with the type of banana cultivars $(p=0.005)$, where the severity was three and seven times lower in farms with a mixture of both indigenous and improved cultivars compared with farms with either improved or indigenous cultivars alone, respectively (Table 1). The results may be explained by increased genetic diversity in cultivars mixtures, which contributes to variation in insect visiting the male flowers depending on the availability of their favorite cultivars (Tooker and Frank 2012). This is the first report that demonstrated the association of cultivars mixture with low severity of Xanthomonas wilt. A detailed study should be conducted to understand the mechanisms behind these findings.

\subsection{Farmers awareness, control practices, and source of information for Xanthomonas wilt}

\subsubsection{Awareness on Xanthomonas wilt detection and spread}

The majority of interviewed farmers (53 to $93 \%$ in all districts) could detect banana Xanthomonas wilt by wilting symptoms (Table 2A). This is obviously explained by the local name given to the disease "Kirabiranya", which means "causing wilting". Fifty-five percent of the farmers knew the symptoms of fruit premature ripening. These findings are consistent with those of Night et al. (2013) that most farmers in Rwanda could detect Xanthomonas wilt by looking at wilting leaves and premature ripening of the fruits. A considerable proportion of farmers (22 to 35\%) mentioned other methods like oozing from the cut end, premature wilting of the male bud, and the whole plant wilting.

Farm tools and insects were identified as the major transmission means for the Xanthomonas wilt causing pathogen (Tinzaara et al. 2011), and the majority of interviewees in this study (70\% and 58\%) were aware of these means respectively (Table 2A). Other spread methods mentioned include infected plants and planting materials (36\%), grazing animals $(25 \%)$, not decomposed banana wastes (13\%), and infested soil $(15 \%)$ (Table 2A). The farmers surveyed in this study did not know about the spread by rain or water. Low awareness of Xanthomonas campestris pv. musacearum spread by water and soil by the farmers in Rwanda was also shown by Night et al. (2013). However, Shimwela et al. (2016) confirmed that the Xanthomonas wilt causing pathogen is heavily spread by rainwater, henceforth advising farmers to prune and remove infected bananas in the dry season.
3.3.2 Awareness and practice of Xanthomonas wilt control measures

The recommended practices to control Xanthomonas wilt in Rwanda include consistent removal of infected mats, burying or burning infected residues, sterilization of farm tools, and timely removal of the male buds (Murekezi 2009; Rutikanga et al. 2013). The large majority of respondent farmers (> 70\%) were aware of uprooting infected bananas and removal of the male bud to control Xanthomonas wilt, while $78 \%$ and $65 \%$ farmers implement the removal of symptomatic plants and the male buds respectively to manage the disease (Table $2 \mathrm{~A}$ and B). In addition, $35 \%$ farmers bury or burn infected banana residues, 33 to $38 \%$ practice the whole mat removal, tools sterilization and avoidance of exchanging tools or planting materials (Table 2B). Only 9\% farmers use suckers from certified multipliers. These results show that farmers tend to implement disease control measures that are easy for them to implement, such as the removal of symptomatic plants on the mat instead of the whole mat and male buds removal. A recent study recommends single diseased stem removal technology as an alternative to the whole mat removal based on the finding that adjacent or physically attached shoots of an infected plant are sometimes healthy (Blomme et al. 2017). The technique is easily applicable for farmers and can significantly reduce the disease but requires consistent use with the other disease management methods. Thus, the management of Xanthomonas wilt remains knowledge and labor intensive and imposes continuous training and extension efforts (McCampbell et al. 2018).

There is an inconsistency between disease awareness and application of Xanthomonas wilt management options in the surveyed districts. Similarly, the proportion of farmers applying components of a disease management package differs within districts. These results agree with previous findings that some farmers ignore or drop practices in the recommended disease management package thus limiting the potential for successful control of the disease (Jogo et al. 2013; Rutikanga et al. 2013; Tinzaara et al. 2011). Furthermore, the awareness and application of disease management by the farmers in this study are slightly higher than those observed during 2009-2010 by Night et al. (2013). On the other hand, the disease incidence observed by Night et al. (2013) was lower compared with the incidence reported in this study. These results are probably due to farmers' reluctance to correctly apply the recommended management practices considering the disease persistence in their farms or neighboring farms and the magnitude of Xanthomonas campestris pv. musacearum spread. Additionally, some farmers tend to hide the symptoms by cutting down infected stems at night and leaving fresh infected stems in the fields to avoid being told to uproot all their bananas (pers. communication with Rusizi and Nyamasheke local leaders). Cutting down infected 
Table 2 Percentage of farmers' awareness, control practices, and information sources for banana Xanthomonas wilt disease in ten districts of Rwanda $(n=150)$ during March-April 2015 and 2016

Awareness, control practices, and knowledge sources ${ }^{\mathrm{a}} \quad$ Surveyed agro-ecological zones and districts $^{\mathrm{b}}$

Overall $(\%)$

$\frac{\text { Central Plateau }}{\text { Huye Nyam }} \frac{\text { Buberuka }}{\text { Rul Gic }} \frac{\text { Birunga }}{\text { Nyab Mus }} \frac{\text { Eastern Plateau }}{\text { Rwam Kay }} \frac{\text { Impara }}{\text { Rus Nyke }}$

A. Farmers' aware of detection, spread and management methods for Xanthomonas wilt (\%)

BXW Detection awareness

Wilting/yellowing of the leaves

Premature ripening of the fruit

Pus like substances on the cut end

Premature rotting of the male bud

The whole plant wilt

Bad smell from the cut end

Discoloration in the heart of stem

No idea

BXW Spread awareness

Contaminated farm tools

Bees/insects/flying animals

Infected plants/planting materials

Grazing animals

Infected soil

Undecomposed banana wastes

No idea

BXW control awareness

Uprooting infected banana

Burying /burning infected materials

Sterilization of farm tools

Removal of the male bud

Avoidance of sharing farm tools

Rotation with other crops for 2 years

Avoid movement of banana plants

Use healthy suckers

No idea

$\begin{array}{rrrrr}80 & 60 & 67 & 53 & 67 \\ 47 & 27 & 73 & 33 & 27 \\ 20 & 0 & 47 & 40 & 27 \\ 13 & 47 & 67 & 33 & 27 \\ 33 & 33 & 27 & 0 & 0 \\ 0 & 0 & 0 & 27 & 0 \\ 13 & 27 & 0 & 0 & 0 \\ 0 & 13 & 0 & 0 & 0\end{array}$

$\begin{array}{rr}67 & 73 \\ 40 & 27 \\ 47 & 33 \\ 20 & 13 \\ 7 & 0 \\ 7 & 0 \\ 0 & 27\end{array}$

$\begin{array}{lll}87 & 80 & 93\end{array}$

$\begin{array}{lll}67 & 53 & 20\end{array}$

$\begin{array}{lll}0 & 47 & 40\end{array}$

$\begin{array}{lll}0 & 33 & 33\end{array}$

$\begin{array}{lll}0 & 0 & 7\end{array}$

$\begin{array}{rrr}0 & 0 & 0 \\ 13 & 0 & 0\end{array}$

$\begin{array}{rr}100 & 53 \\ 40 & 7\end{array}$

$47 \quad 0$

$73 \quad 33$

$33 \quad 33$

130

$20 \quad 0$

$47 \quad 13$

$\begin{array}{rrr}100 & 60 & 67 \\ 80 & 33 & 60 \\ 73 & 33 & 33 \\ 80 & 93 & 40 \\ 47 & 27 & 20 \\ 0 & 0 & 0 \\ 80 & 73 & 0 \\ 0 & 0 & 0 \\ 0 & 7 & 7\end{array}$

$\begin{array}{rr}73 & 53 \\ 33 & 73 \\ 33 & 47 \\ 20 & 33 \\ 20 & \\ 0 & \\ 0 & 13 \\ 0 & \end{array}$

$53-80$

$\begin{array}{lll}93 & 87 & 71\end{array}$

B. Farmers practicing control measures (\%)

Symptomatic plant removal

Whole mat removal

Male bud removal

Burying/burning infected residues

Tools sterilization with fire or JIK

Avoid sharing tools

Avoid exchange of planting materials

Use suckers from certified multipliers

$\begin{array}{rrrrr}80 & 53 & 100 & 60 & 67 \\ 47 & 27 & 40 & 13 & 27 \\ 73 & 33 & 80 & 60 & 33 \\ 20 & 7 & 53 & 33 & 33 \\ 20 & 0 & 67 & 33 & 27 \\ 33 & 33 & 33 & 13 & 20 \\ 20 & 0 & 0 & 0 & 0 \\ 7 & 0 & 0 & 0 & 0\end{array}$

$\begin{array}{rrrrrr}53 & 100 & 80 & 87 & 100 & 78 \\ 27 & 20 & 33 & 47 & 60 & 34 \\ 47 & 80 & 80 & 67 & 93 & 65 \\ 40 & 60 & 33 & 53 & 40 & 37 \\ 40 & 33 & 47 & 20 & 53 & 34 \\ 47 & 47 & 27 & 53 & 73 & 38 \\ 0 & 80 & 73 & 73 & 87 & 33 \\ 0 & 20 & 20 & 13 & 27 & 9\end{array}$

C. Source of knowledge for BXW (\%)

Agronomists
Brochures
Extension officer
Fellow farmers
Local leader
MINAGRI staffs
News papers
NGOs
Parents/relatives
Posters
RAB scientists
Radio
Researchers
Television
Training

$\begin{array}{rrrrr}40 & 13 & 27 & 40 & 80 \\ 13 & 0 & 0 & 0 & 20 \\ 53 & 0 & 13 & 7 & 13 \\ 80 & 53 & 73 & 93 & 80 \\ 40 & 13 & 33 & 27 & 33 \\ 0 & 0 & 20 & 0 & \\ 0 & 0 & 0 & 0 & 0 \\ 7 & 0 & 7 & 0 & \\ 27 & 27 & 40 & 60 & 73 \\ 0 & 13 & 0 & 0 & \\ 20 & 0 & 13 & 0 & 0 \\ 13 & 7 & 20 & 7 & \\ 13 & 0 & 0 & 0 & 0 \\ 0 & 0 & 0 & 0 & 0 \\ 13 & 0 & 0 & 0 & 0\end{array}$

${ }^{\text {a }} B X W$ banana Xanthomonas wilt, MINAGRI Ministry of Agriculture and Animal Resources, NGO's Non-Government Organizations, $R A B$ Rwanda Agriculture Board. ${ }^{b}$ Surveyed districts are Nyam Nyamagabe, Rul Rulindo, Gic Gicumbi, Nyab Nyabihu, Mus Musanze; Rwam Rwamagana, Kay Kayonza, Rus Rusizi, Nyke Nyamasheke 
bananas and leaving them in the farm create a place for the bacteria to survive and potentially spread by rainwater (Shimwela et al. 2016). Some disease management practices are common in some districts and rarely practiced in others (Table 2B). For instance, the avoidance of exchanging planting materials is practiced by 73 to $87 \%$ farmers in major banana growing districts and $20 \%$ farmers in Huye but not implemented in other districts. This could be due to the importance that the farmers attribute to the crop or that the farmers are unaware of management methods, as observed in Nyamagabe where none of the farmers is aware of tools sterilization for management of Xanthomonas wilt and hence the method is not practiced.

\subsubsection{Source of knowledge of banana Xanthomonas wilt}

The knowledge source plays an important role in the quality of displayed information. The major source of knowledge in this study is fellow farmers (80\%) followed by local leaders (53\%) and agricultural officers (53\%) (Table 2C). If the information providers have wrong or incomplete information, the shared information is incorrect. The farmers that received information from trusted sources like extension officers, researchers, Rwanda Agriculture Board Scientists, MINAGRI, and NGOs are limited and these sources mainly reached farmers in the major banana growing districts. And some farmers (13\% in Huye, 27\% in Rusizi, and 53\% in Nyamasheke districts) received trainings by Rwanda Agriculture Board staffs, MINAGRI, and local NGOs. None of the surveyed farmers received information from television or newspaper. These findings indicate the need to improve the information distribution channels and the quality of information used, to ensure that the accurate information reaches the farmers who are the final implementers. Among the agricultural extension officers that provided information to the farmers include the facilitators in agriculture and farmer promoters who operate under the "Twigire muhinzi" extension program already in place in Rwanda (Anonymous 2016). These farmer field school facilitators and farmer promoters reach a big number of farmers, speak in their language, and sensitize farmers in several aspects of good farming practices (Anonymous 2016). Hence, they are good communicators but need consistent trainings and updates on specific aspects like detection, spread, and management of emerging diseases. Moreover, local leaders and agronomists, who are also shown as important providers of information to farmers in this study, need to be well equipped with a complete package of information about Xanthomonas wilt management or any other emerging disease, and they should be facilitated with a specific budget in order to reach the farmers on time.

Our study shows that the disease has increased since the previous report in Rwanda (Night et al. 2013) and has spread to new areas. We demonstrated for the first time the seriousness of Xanthomonas wilt in the major banana growing districts of Rwanda. This will cause considerable impact on food security and call for reinforcement of disease management and information distribution. The disease could be controlled by applying properly the control measures as a package (Blomme et al. 2017). The association we found that cultivars mixture is associated with low severity of Xanthomonas wilt is useful for developing sustainable management strategy for the disease.

\section{Conclusions}

Banana Xanthomonas wilt continues to be an important threat to banana in Rwanda and the Great Lakes region of East and Central Africa where banana is an important crop. By combining disease survey and interviews, this study identified several factors that influence banana Xanthomonas wilt occurrence in Rwanda: agro-ecological locations; farming practices like cropping systems, spacing, banana types, and grown cultivars; farmers' knowledge; application of disease management; and information distribution channels. Future Xanthomonas wilt management extension efforts should take into consideration the effects of practices like intercropping, dense spacing, and homogeneity in grown cultivars on high disease occurrence and the agro-ecological zones in high risk of disease. We reported for the first time the link between cultivars mixture and low disease severity. These findings should be utilized by planners as a basis to develop sustainable disease management approach.

Considering the observed high occurrence of Xanthomonas wilt in major banana growing areas, and the importance of banana to the livelihood of farmers, there is a need to improve the implementation of management methods as a complete package. It is essential to enhance the information used by information distribution channels in order to ensure that the right information reaches the farmer. All stakeholders including farmers need to work jointly together to address this problem. Supporting early detection of the disease and exchanging information rapidly in order to make quick and appropriate decisions about control strategies will help to reduce the impact of the disease. Moreover, involving banana farmers in disease surveillance, extension, and decision-making would motivate them to own the problem.

Acknowledgments The authors greatly acknowledge the funding institutions for the financial support rendered to the corresponding author. We are also grateful to Cajsa Lithell and interviewed farmers.

Funding This study was financially supported by the Swedish International Development Cooperation Agency (Sida) through the URSweden Program for Research, Higher Education and Institutional Advancement. 


\section{Compliance with ethical standards}

Conflict of interest The authors declare that they have no conflict of interest.

Open Access This article is distributed under the terms of the Creative Commons Attribution 4.0 International License (http:// creativecommons.org/licenses/by/4.0/), which permits unrestricted use, distribution, and reproduction in any medium, provided you give appropriate credit to the original author(s) and the source, provide a link to the Creative Commons license, and indicate if changes were made.

\section{References}

Akaike H (1974) A new look at the statistical model identification. IEEE Trans Automat Contr 19(6):716-723. https://doi.org/10.1109/TAC. 1974.1100705

Anonymous (2016) Twigire Muhinzi reflection paper. Ministry of Agriculture and Animal Resources of the Republic of Rwanda \& the Belgian Development Agency, Kigali https://issuu.com/ rafsomers/docs/twigire_muhinzi_ffs_fp_reflection. Accessed 8 Nov 2018

Blomme G, Ocimati W, Sivirihauma C, Vutseme L, Mariamu B, Kamira M, van Schagen B, Ekboir J, Ntamwira J (2017) A control package revolving around the removal of single diseased banana stems is effective for the restoration of Xanthomonas wilt infected fields. Eur J Plant Pathol 149(2):385-400. https://doi.org/10.1007/ s10658-017-1189-6

Carter BA, Reeder R, Mgenzi SR, Kinyua ZM, Mbaka JN, Doyle K, Nakato V, Mwangi M, Beed F, Aritua V, Lewis Ivey ML, Miller SA, Smith JJ (2010) Identification of Xanthomonas vasicola (formerly $X$. campestris pv. musacearum), causative organism of banana Xanthomonas wilt, in Tanzania, Kenya and Burundi. Plant Pathol 59(2):403. https://doi.org/10.1111/j.1365-3059.2009.02124. $\mathrm{X}$

Everitt B, Hothorn T (2006) Logistic regression and generalised linear models: blood screening, women's role in society, and colonic polyps. In: A handbook of statistical analyses using R, 2nd edn. CRS Press Taylor and Francis Group, York, pp 117-138

Jaworski T, Hilszczański J (2013) The effect of temperature and humidity changes on insects development their impact on forest ecosystems in the expected climate change. For Res Pap 74(4):345-355. https:// doi.org/10.2478/frp-2013-0033

Jogo W, Karamura E, Tinzaara W, Kubiriba J, Rietveld A (2013) Determinants of farm-level adoption of cultural practices for banana Xanthomonas wilt control in Uganda. J Agric Sci 5(7):70-81. https://doi.org/10.5539/jas.v5n7p70

Karamura E, Turyagyenda F, Tinzara W, Blomme G et al (2008) Xanthomonas wilt of bananas in East and Central Africa. Diagnostic and management guide. Bioversity International, Kampala

Karamura D, Karamura E, Tinzaara W (2012) Banana cultivar names, synonyms and their usage in Eastern Africa. Bioversity International, Kampala

Kubiriba J, Tushemereirwe W (2014) Approaches for the control of banana Xanthomonas wilt in East and Central Africa. African J Plant Sci 8(8):398-404. https://doi.org/10.5897/AJPS2013.1106

McCampbell M, Schut M, Van den Bergh I, Van Schagen B et al (2018) Xanthomonas wilt of banana (BXW) in Central Africa: opportunities, challenges, and pathways for citizen science and ICT-based control and prevention strategies. NJAS Wagen J Life Sc 86-87: 89-100. https://doi.org/10.1016/j.njas.2018.03.002
Murekezi C (2009) Xanthomonas wilt management in Rwanda. In: proceedings of the workshop on the review of the Strategy for the management of banana Xanthomonas wilt. Bioversity International, Kigali, pp 16-20

Mwangi M, Nakato V (2009) Key factors responsible for the Xanthomonas wilt epidemic on banana in east and central africa. Acta Hortic 828:395-404. https://doi.org/10.17660/ActaHortic. 2009.828 .41

Mwangi M, William T, Ndungo V, Flora N, Philip R, Ranajit B (2006) Comparative study of banana Xanthomonas wilt spread in mid and high altitudes of the Great Lakes region of Africa. Conference on international Agricultural Research for Development, Bonn. https:// doi.org/10.13140/RG.2.1.3874.7765

Night G, Gaidashova S, Nyirigira A, Mugiraneza T et al. (2013) Distribution, incidence and farmer knowledge of banana Xanthomonas wilt in Rwanda. In: Banana systems in the humid highlands of sub-Saharan Africa. CABI, London, pp 131-137. https://doi.org/10.1079/9781780642314.0131

NISR (2016) Seasonal agricultural survey 2015. National Institute of Statistics of Rwanda. http://www.statistics.gov.rw/publication/ seasonal-agricultural-survey-report-2015. Accessed 15 May 2018

Nkuba J, Tinzaara W, Night G, Niko N et al (2015) Adverse impact of Banana Xanthomonas wilt on farmers livelihoods in eastern and Central Africa. African J Plant Sci 9(7):279-286. https://doi.org/ 10.5897/AJPS2015.1292

Nsabimana A, Gaidashova SV, Nantale G, Karamura D, Van Staden J (2008) Banana cultivar distribution in Rwanda. Afr Crop Sci J 16(1):1-8. https://doi.org/10.4314/acsj.v16i1.54318

Ocimati W, Ssekiwoko F, Buttibwa M, Karamura E, Tinzaara W, EdenGreen S, Blomme G (2013) Systemicity and speed of movement of Xanthomonas campestris pv. musacearum in the banana plant after garden tool-mediated infection. In: Banana Systems in the Humid Highlands of sub-Saharan Africa. CABI, London, pp 101-107. https://doi.org/10.1111/j.1365-3059.2012.02697.x

Reeder R, Muhinyuza J, Opolot O, Aritua V, Crozier J, Smith J (2007) Presence of banana bacterial wilt (Xanthomonas campestris pv. musacearum) in Rwanda. Plant Pathol 56(6):1038-1038. https:// doi.org/10.1111/j.1365-3059.2007.01640.x

Rutikanga A, Sivirihauma C, Murekezi C, Anuarite U et al (2013) Banana Xanthomonas wilt management: effectiveness of selective mat uprooting coupled with control options for preventing disease transmission. Case study in Rwanda and Eastern Democratic Republic of Congo. In: Banana Systems in the humid highlands of sub-Saharan Africa. CABI, London, pp 116-124

Shimwela MM, Ploetz RC, Beed FD, Jones JB, Blackburn JK, Mkulila SI, Van Bruggen AH (2016) Banana Xanthomonas wilt continues to spread in Tanzania despite an intensive symptomatic plant removal campaign: an impending socio-economic and ecological disaster. Food Secur 8(5):939-951. https://doi.org/10.1007/s12571-0160609-3

Tinzaara W, Karamura E, Blomme G, Jogo W, Ocimati W, Rietveld A, Kubiriba J, Opio F (2011) Why sustainable management of Xanthomonas wilt of banana in East and Central Africa has been elusive. Acta Hortic 986:157-164. https://doi.org/10.17660/ ActaHortic.2013.986.16

Tooker JF, Frank SD (2012) Genotypically diverse cultivar mixtures for insect pest management and increased crop yields. J Appl Ecol 49(5):974-985. https://doi.org/10.1111/j.1365-2664.2012.02173.x

Tripathi L, Mwangi M, Abele S, Aritua V, Tushemereirwe WK, Bandyopadhyay R (2009) Xanthomonas wilt: a threat to banana production in East and Central Africa. Plant Dis 93(5):440-451. https://doi.org/10.1094/PDIS-93-5-0440

Tushemereirwe W, Benin S, Blomme G, Eden Green S, Markham R, Karamura E, Kayobyo G (2008) Assessing the impacts of banana bacterial wilt disease on banana (Musa spp.) productivity and 
livelihoods of Ugandan farm households. Acta Hortic 879:749-755. https://doi.org/10.17660/ActaHortic.2010.879.81

Uwamahoro F, Berlin A, Bylund H, Bucagu C, Yuen J (2018) Potato bacterial wilt in Rwanda: occurrence, risk factors, farmers' knowledge and attitudes. Food Secur 10:1221-1235. https://doi.org/10. 1007/s12571-018-0834-Z

Verdoodt A, Van Ranst E (2006) Environmental assessment tools for multi-scale land resources information systems: a case study of Rwanda. Agric Ecosyst Environ 114:170-184. https://doi.org/10. 1016/j.agee.2005.10.006
Yirgou D, Bradbury J (1974) A note on wilt of banana caused by the enset wilt organism Xanthomonas musacearum. East Afr Agric For J 40(1):111-114. https://doi.org/10.1080/00128325.1974.11662720

Publisher's note Springer Nature remains neutral with regard to jurisdictional claims in published maps and institutional affiliations. 